\title{
Panggilan Sosial Gereja Berdasarkan Pelayanan Yesus Dalam Lukas 4:18-19: Sebuah Upaya Merevitalisasi Pelayanan Gereja
}

\section{Social Responsibility of the Church based on Jesus' Ministry in Luke 4:18-19: An Attempt to Revitalize Church Ministry}

\author{
Herry Susanto \\ Sekolah Tinggi Alkitab Tiranus, Bandung \\ Korespondensi: herrysusanto@tiranus.ac.id
}

\begin{abstract}
Abstrak: Salah satu unsur penting dalam pelayanan gereja yang terabaikan adalah peran sosial gereja untuk mewujudkan kesejahteraan. Padahal warga jemaat berhadapan dengan berbagai isu sosial. Salah satu yang cukup krusial adalah kemiskinan. Dalam upaya merevitalisasi pelayanan gereja, salah satu yang perlu diwujudkan adalah integrasi antara kepedulian sosial dan pelayanan gereja. Artikel ini akan menjelaskan bahwa gereja memiliki panggilan dan tanggung jawab sosial. Fondasi bagi gagasan ini adalah karakteristik pelayanan Yesus yang termuat dalam Lukas 4:18-19, yang merupakan kutipan dari Yesaya 61:1-2; 58:6. Berdasarkan penggunaan Yesaya 61:1-2 yang dikombinasikan dengan Yesaya 58:6, artikel ini menunjukkan bahwa penulis Injil Ketiga memodifikasi kutipan tersebut untuk memperkuat karakteristik sosial dalam pelayanan Yesus. Dimensi sosial pelayanan Yesus merupakan landasan penting untuk membangun pelayanan gerejawi yang memiliki kesadaran sosial untuk membentuk kehidupan umat secara menyeluruh. Dalam menguraikan gagasannya, artikel ini akan menerapkan metode kualitatif yang berorientasi pada studi literatur dan analisis hermeneutika. Adapun pendekatan hermeneutika yang akan diterapkan berfokus pada pembacaan Injil sebagai biografi Yunani-Romawi. Prinsip-prinsip yang umum digunakan dalam metode kritik naratif juga akan diterapkan. Karena adanya kutipan dari Kitab Yesaya, pendekatan hermenutika yang digunakan juga akan menganalisis cara penulis Injil Ketiga menggunakan teks Yesaya tersebut. Artikel ini akan berfokus pada tiga aspek, yaitu karakteristik sosial Injil Ketiga, karakteristik sosial pelayanan Yesus berdasarkan Lukas 4:18-19, dan implikasi dimensi sosial pelayanan Yesus bagi upaya revitalisasi pelayanan gereja.
\end{abstract}

Kata kunci: Pelayanan Gereja, Panggilan Sosial Gereja, Revitalisasi Pelayanan Kristen, Injil Lukas, Kitab Yesaya

\begin{abstract}
One important element that neglected in church ministry is the social responsibility of the church in realizing the well-being of the community. Whereas the congregation is dealing with various social issues. One that is quite crucial is poverty. In an effort to revitalize church ministry, one that needs to be realized is the integration of social care and church ministry. This article will explain that the church has social calling and responsibility. The foundation for this idea is the characteristics of Jesus' ministry conveyed by Luke 4:18-19, which is a quotation from Isaiah 61:1-2; 58:6. Based on the use of Isaiah 61:1-2 combined with Isaiah 58:6, this article shows that the writer of the Third Gospel modified the quotation to strengthen social characteristics in Jesus' ministry. The social dimension of Jesus' ministry is an important foundation for building church ministries that have social awareness to shape the lives of believers holistically. This article will apply qualitative methods that focus on literary study and hermeneutical analysis. The hermeneutical approach applied here focuses on reading the Gospels as Greco-Roman biography. The principles commonly used in narrative criticism will also be applied. Because of the quotation from the Book of Isaiah, this article will also analyze the way the writer of the Third Gospel used the text of Isaiah. This article will focus on three aspects, namely the social characteristics of the Third Gospel, the social characteristics of Jesus' ministry based on Luke 4: 18-19, and the implications of the social dimension of Jesus' ministry for revitalizing church ministry .
\end{abstract}

Keywords: Church Ministry, Church's Social Responsibility, Revitalizing Christian Ministry, The Gospel of Luke, The Book of Isaiah 


\section{PENDAHULUAN}

Pelayanan Kristen seharusnya mampu menyentuh seluruh kebutuhan umat, termasuk kebutuhan-kebutuhan materiel mereka. Gereja harus memiliki kepekaan dalam melihat fakta bahwa masih banyak umat yang bergumul dengan masalah kemiskinan. Berdasarkan data statistik, angka kemiskinan di Indonesia tertinggi di pulau Maluku dan Papua $(20,94 \%)$. Kedua provinsi tersebut merupakan daerah di mana angka kekristenan tinggi. ${ }^{1}$ Data lebih lengkap berdasarkan pulau dapat dilihat pada tabel di bawah ini. ${ }^{2}$

Tabel 1 Profil Kemiskinan di Indonesia 2018

\begin{tabular}{ll}
\hline Pulau & Persentase (\%) \\
\hline Sumatera & 10,21 \\
Jawa & 8,79 \\
Bali dan Nusa Tenggara & 13,84 \\
Kalimantan & 5,98 \\
Sulawesi & 10,37 \\
Maluku dan Papua & 20,94 \\
Indonesia & 9,66 \\
\hline
\end{tabular}

Salah satu unsur penting dalam pelayanan gereja yang terabaikan adalah peran sosial gereja untuk mewujudkan kesejahteraan. Tingginya angka kemiskinan di beberapa kantong Kristen mengindikasikan hal tersebut. Padahal warga jemaat berhadapan dengan berbagai isu sosial. Salah satu yang cukup krusial adalah kemiskinan. Gereja sepertinya masih sulit menyikapi fakta bahwa kemiskinan begitu dekat dengan warga gereja. Salah satu penyebabnya adalah konsep

${ }^{1}$ Bila dilihat berdasarkan dua provinsi yang ada, yaitu Maluku dan Papua, menurut data Kementerian Agama terdapat kira-kira $48 \%$ pemeluk agama Kristen dan Katolik di Maluku. Sedangkan di Papua kira-kira ada $83 \%$ pemeluk agama Kristen dan Katolik. Data ini diambil dari "Kementerian Agama Dalam Angka 2016" (Biro Hubungan Masyarakat, Data dan Informasi Sekretariat Jenderal Kementrian Agama, 2017), 49.

${ }^{2}$ Berdasarkan "Profil Kemiskinan Di Indonesia September 2018” (Badan Pusat Statistik, 2019), 3. dualisme yang mempengaruhi banyak gereja dalam memahami pelayanan. Konsep dualisme tersebut didasari pada pemahaman bahwa apa yang materiel (jasmani) adalah kesementaraan dan yang imateriel (rohani) adalah kekekalan. Unsur imateriel dianggap lebih penting dari pada materiel. Sehingga tidak heran bila kepedulian sosial (yang merupakan bentuk pelayanan yang memperhatikan kebutuhan jasmani) menjadi pelayanan yang sifatnya sekunder. ${ }^{3}$

Untuk itu, gereja perlu melakukan revitalisasi. Dalam upaya merevitalisasi pelayanan gereja, salah satu yang perlu diwujudkan adalah integrasi antara kepedulian sosial dan pelayanan gereja. Melalui perpaduan antara keduanya, gereja akan mampu menjawab kebutuhan warga jemaat dalam menggumuli masalah kemiskinan, agar restorasi menyeluruh dalam hidup jemaat dapat terwujud. Artikel ini akan menjelaskan bahwa gereja memiliki panggilan sosial. Fondasi bagi gagasan panggilan sosial tersebut adalah karakteristik pelayanan Yesus yang termuat dalam Lukas 4:18-19. Dalam pemaparannya, artikel ini akan berfokus pada tiga aspek, yaitu karakteristik sosial Injil Ketiga, karakteristik sosial pelayanan Yesus berdasarkan Lukas 4:18-19, dan implikasi dimensi sosial pelayanan Yesus bagi upaya revitalisasi pelayanan gereja.

\section{METODOLOGI}

Dalam menguraikan gagasannya, artikel ini akan menerapkan metode kualitatif yang berorientasi pada studi literatur dan analisis hermeneutika. Adapun pendekatan hermeneutika yang akan diterapkan berfokus pada pembacaan teks Injil sebagai tulisan biografi

${ }^{3}$ Akibat pandangan dualisme yang menekankan pemisahan antara realitas materiel dan imateriel, gereja cenderung beranggapan bahwa perhatian terhadap isuisu sosial bukanlah tanggung jawab gereja, karena realitas materiel dianggap lebih rendah dari pada imateriel. Lih. Amos Sukamto, Pelayanan Gereja Di Indonesia Pada Era Reformasi (Jakarta: Tim Publikasi ICDS, 2003), 140. 
Yunani-Romawi. Di samping itu juga akan diterapkan prinsip-prinsip yang umum digunakan dalam metode kritik naratif. Artikel ini juga akan menggunakan pendekatan intertekstualitas untuk menyoroti cara penulis Injil Ketiga menggunakan teks Yesaya 61:12; 58:6 yang dikutip olehnya.

Dalam artikel ini, penulis berasumsi bahwa genre Injil adalah bios, biografi YunaniRomawi. Salah satu karakteristik penting dari bios adalah fokus pada satu tokoh utama yang menjadi dasar bagi gagasan yang ingin disampaikan oleh penulis bios tersebut. Karena itu, artikel ini akan berfokus kepada Yesus sebagai tokoh utama. Pemilihan bios sebagai genre mengindikasikan bahwa para penulis Injil menganggap bentuk ini sebagai cara yang paling efektif untuk mencapai tujuan mereka, yaitu menarik fokus perhatian pembaca kepada pribadi Yesus sebagai pribadi yang menyatakan Allah di dalam seluruh perkataan dan perbuatan-Nya, serta kehidupan, kematian dan kebangkitan-Nya. ${ }^{4}$ Berdasarkan John S. Kloppenborg, tokoh utama menjadi sumber bagi ideologi yang coba disajikan dalam biografi kuno. ${ }^{5}$ Oleh sebab itu artikel ini akan fokus kepada Yesus, khususnya karakteristik pelayanan-Nya.

Unsur penting dari pendekatan kritik naratif yang diterapkan dalam artikel ini adalah kesatuan teks. Kritik naratif tidak melihat teks secara terfragmentasi, melainkan sebagai satu kesatuan yang bagian-bagiannya saling terkait. ${ }^{6}$ Bertolak dari prinsip kesatuan teks ini, Lukas 4:18-19 akan dianalisis secara

${ }^{4}$ Richard Burridge, "Gospel Genre, Christological Controversy and the Absence of Rabbinic Biography: Some Implications of the Biographical Hypothesis," dalam Christology, Controversy and Community: New Testament Essays in Honor of David R. Catchpole, ed. David G. Horrell and Christopher M. Tuckett (Leiden: Brill, 2000) 153.

5John S. Kloppenborg, "Gospels," in The Oxford Encyclopedia of the Books of the Bible, ed. Michael Coogan (Oxford: Oxford University Press, 2011), 1:342.

${ }^{6}$ James L. Resseguie, Narrative Criticism of the New Testament: An Introduction (Grand Rapids: Baker Academic, 2005), 38. terkait dengan perikop-perikop lain dari Injil Lukas yang relevan bagi pembahasan topik artikel ini. Jadi prinsip kritik naratif yang diterapkan berorientasi pada keutuhan teks Injil. Penerapan prinsip ini terlihat pada bagian analisis konteks yang menghubungkan Lukas 4:18-19 dengan Lukas 3:21-7:22.

Selain pendekatan kritik naratif, artikel ini juga akan menyoroti modifikasi yang dilakukan oleh penulis Injil Lukas terhadap teks Yesaya 61:1-2; 58:6. Secara intertekstual akan digali ide yang terkandung dalam $\mathrm{Lu}-$ kas 4:18-19 berdasarkan tujuan dari penulis Injil dalam memadukan Yesaya 61:1-2 dengan 58:6, dan mengabaikan bagian tertentu dari Yesaya 61:1-2. Penerapan pendekatan ini akan terimplementasi pada bahasan modifikasi kutipan dari Kitab Yesaya.

\section{DIMENSI SOSIAL INJIL LUKAS}

Injil Lukas menampilkan pelayanan Yesus dengan dimensi sosial yang kuat. Hal ini tentu terkait dengan tujuan penulisan dari Injil Ketiga. Henry J. Cadbury dalam penjelasannya mengenai unsur sosial dari Injil Lukas, menyebutkan bahwa Injil ini memiliki simpati kepada orang-orang miskin, serta interes terhadap kemiskinan dan kedermawanan. ${ }^{7}$

Bila melihat narasi Lukas secara utuh maka akan didapati bahwa keselamatan menjadi salah satu tema penting. Lebih spesifik, Lukas ingin menunjukkan bahwa keselamatan tersebut diperuntukkan bagi semua orang. Yesus yang merupakan tokoh utama dari Injil Ketiga, diperkenalkan sebagai Juru Selamat (Luk. 2:11). Hal yang unik dengan Injil ini adalah orang-orang yang berinteraksi dengan Yesus selama pelayanan-Nya, umumnya adalah mereka yang secara sosial

${ }^{7}$ Henry J. Cadbury, The Making of Luke-Acts (Peabody: Hendrickson, 1999), 260-261; lihat juga Amanda C. Miller, "Bridge Work and Seating Charts: A Study of Luke's Ethics of Wealth, Poverty, and Reversal," Interpretation: A Journal of Bible and Theology 68, no. 4 (2014): 416-427. 
terpinggirkan. Dengan kenyataan tersebut, Injil Lukas menyampaikan bahwa keselamatan dari Allah telah hadir untuk mereka yang mengalami diskriminasi. ${ }^{8}$ Dengan demikian keselamatan yang dihadirkan oleh Injil Ketiga memiliki dimensi praktis, yaitu per-hatian terhadap mereka yang lemah.

Hubungan antara keselamatan dan praktik kepedulian sosial terlihat dalam kisah Zakheus (Luk. 19:1-10). Keberadaan Zakheus mewakili komunitas yang terdiskriminasi. Teks menunjukkan hal tersebut melalui pernyataan orang-orang di sekitar rumah $\mathrm{Za}$ kheus ketika Yesus makan di rumahnya: "Ia menumpang di rumah orang berdosa" (Luk. 19:7). Hal menarik dari kisah ini adalah tiga ayat terakhir yang menjadi elemen penting yang menghubungkan narasi Zakheus dengan kerangka besar Injil Lukas, yaitu keterkaitan antara keselamatan dan kepedulian sosial.

Pernyataan orang-orang dalam Lukas 19:7 dilanjutkan dengan pernyataan Zakheus: "Tuhan, setengah dari milikku akan kuberikan kepada orang miskin dan sekiranya ada sesuatu yang kuperas dari seseorang akan kukembalikan empat kali lipat” (Luk. 19:8). Poin dari perikop ini adalah perkataan Yesus sebagai respons terhadap perkataan Zakheus: "Hari ini telah terjadi keselamatan kepada rumah ini, karena orang ini pun anak Abraham. Sebab Anak Manusia datang untuk mencari dan menyelamatkan yang hilang" (Luk. 19:9-10). Jadi ayat 8-10 memperlihatkan keterkaitan antara keselamatan dan kepedulian terhadap mereka yang miskin atau lemah secara sosial. Keselamatan yang telah dimiliki oleh Zakheus secara praksis terlihat pada keinginannya untuk membagikan sebagian hartanya kepada yang miskin. Sikap kepedulian sosial Zakheus merupakan wujud dari keselamatan yang telah diterimanya. ${ }^{9}$

\footnotetext{
${ }^{8}$ Joel B. Green, The Gospel of Luke, The New International Commentary on the New Testament (Grand Rapids: Eerdmans, 1997), 23.
}

Selain kisah Zakheus, kisah awal dari Injil Lukas (kisah kelahiran Yesus) mengindikasikan motif penulis yang mencoba menggambarkan Yesus sebagai Sang Mesias yang dekat kepada mereka yang terpinggirkan. Bagian awal tersebut tidak hanya sekadar menunjukkan bahwa Yesus adalah Sang Mesias yang menggenapi pengharapan mesianik dalam tradisi Yahudi (Luk. 1:27, 69). Yesus juga diidentikkan dengan karya Allah yang berpihak kepada yang miskin, bahkan asal Yesus sendiri adalah dari keluarga yang berstrata rendah. Di samping itu, status kedua orang tua-Nya dan gembala yang menyambut kelahiran-Nya, mengindikasikan bahwa Lukas melukiskan Yesus sebagai sosok yang ada di sekitar mereka yang terpinggirkan. Dalam menyoroti kepergian Yusuf dan Maria ke Betlehem, kelahiran Yesus dan kunjungan para gembala, Luke Timothy Johnson menjelaskan:

They are also portrayed as being among the poor of the land. However we construe the manger and the lodge and the wrapping bands put on the baby and the visit by shepherds, there is no doubt concerning Luke's portrayal of the economic or social level of Jesus' first companions. Perhaps the shepherds are not to be assessed as "sinners" as they are in the later rabbinic materials (d. e.g., m.Qidd. 4:14; m.Bab.Qam. 10:9), but they are certainly among the lowest-esteemed laborers. Mary and Joseph, in turn, are transients, equivalent to "the homeless" of contemporary city streets, people who lack adequate shelter. ${ }^{10}$

Masih ada beberapa bagian lain yang menunjukkan perhatian Lukas terhadap mere-

${ }^{9}$ Sikap Zakheus jelas merupakan tanda keselamatan. Lih. Duleep de Chickera "Victim Theology and the Economy of Life: Some Lessons," Ecumenical Review 67, no. 2 (2015): 281.

${ }^{10}$ Luke Timothy Johnson, The Gospel of Luke, ed. Daniel J. Harrington, Sacra Pagina Series 3 (Collegeville: The Liturgical, 1991), 52. 
ka yang lemah dan terpinggirkan secara sosial. Pertama, Lukas menekankan tentang kebaikan terhadap mereka yang miskin. Hal ini ditunjukkan melalui perintah untuk menggunakan harta sebagai sedekah. Ketika Yesus menegur kemunafikan seorang Farisi, Dia memerintahkan agar orang Farisi tersebut memberi sedekah sebagai wujud perhatian terhadap keadilan dan kasih (Luk. 11:41, 42). Perintah memberi sedekah juga disampaikan oleh Yesus ketika mengajarkan agar para pengikut-Nya tidak perlu khawatir tentang kehidupan mereka (Luk. 12:33). Perintah yang sama Yesus sampaikan kepada seorang pemimpin yang datang kepadaNya bertanya tentang cara memperoleh hidup kekal (Luk. 18:22).

Kedua, landasan teologis kedatangan Yesus Kristus adalah karakter karya Allah, yang salah satunya adalah keberpihakan kepada mereka yang miskin. Hal ini jelas terlihat pada Nyanyian Maria yang menghubungkan kedatangan Sang Juruselamat dengan pekerjaan Allah. Salah satu bagian dari nyanyian tersebut mengatakan: "Ia melimpahkan segala yang baik kepada orang yang lapar, dan menyuruh orang yang kaya pergi dengan tangan hampa" (Luk. 1:53).

Ketiga, indikasi dimensi sosial yang kuat juga terlihat dalam "Ucapan Bahagia" versi Lukas (6:20-26). Dalam ayat 20-23, Lukas mencatat bahwa mereka yang terpinggirkan adalah yang bersukacita (yang miskin, lapar, dan dikucilkan). Mereka yang berbahagia tersebut kemudian dikontraskan dengan mereka yang secara status terpandang, yang dianggap sebagai orang-orang yang celaka (ay. 24-26). Pengontrasan ini adalah upaya Lukas menunjukkan perhatian Allah terhadap mereka yang termarginalkan. ${ }^{11}$

Di samping itu, kisah di Nazaret (Luk. 4:1630) juga menunjukkan dimensi sosial yang

${ }^{11}$ David A. DeSilva, An Introduction to the New Testament: Contexts, Methods \& Ministry Formation (Downers Grove: InterVarsity Press, 2004), 325. kuat dalam Injil Lukas. Hal tersebut tercermin melalui misi Yesus yang membawa kabar baik bagi mereka yang miskin (Luk. 4:18). Karakteristik pelayanan Yesus tersebut sekaligus menjelaskan karakteristik keselamatan dalam Injil Lukas. Injil ini memperlihatkan bahwa keselamatan memiliki dimensi pembebasan terhadap mereka yang marginal. ${ }^{12}$

Dari bagian ini terlihat bahwa Injil Lukas kental dengan motif sosial. Yesus yang dituturkan dalam Injil Ketiga digambarkan sebagai Mesias yang dalam pelayanan-Nya memiliki perhatian terhadap mereka yang secara sosial lemah. Di bagian selanjutnya, artikel ini akan menggali Lukas 4:18-19 untuk melihat dimensi sosial dari pelayanan Yesus tersebut lebih mendalam.

\section{ANALISIS LUKAS 4:18-19: DIMENSI SOSIAL PELAYANAN YESUS}

Bagian ini akan berfokus pada analisis Lukas 4:18-19. Keberadaan Yesus sebagai tokoh utama akan menjadi sorotan. Sebagaimana diuraikan pada bagian metodologi, salah satu unsur penting dari pembacaan teks Injil sebagai biografi Yunani-Romawi adalah fokus terhadap tokoh utama yang merupakan sumber dari ide yang ingin disampaikan penulis Injil. Oleh sebab itu, dalam tinjauan konteks dan penggunaan teks Yesaya, perhatian besar akan diberikan kepada Yesus sebagai tokoh utama dalam Injil Ketiga. Sebagai perwujudan dari pendekatan kritik naratif yang mengintegrasikan pembacaan teks dengan keseluruhan kitab, pelaporan tentang Yesus dalam Lukas 18-19 akan dihubungkan dengan pelaporan di bagian lain dari Injil Lukas, khususnya Lukas 3:22-7:22. Terkait dengan penggunaan teks Yesaya, bagian ini akan meninjau perubahan yang

\footnotetext{
${ }^{12}$ Susan Calef, “'Prophet Margins' in the Economy of Salvation," dalam The Bible, the Economy, and the Poor, ed. Ronald A Simkins and Thomas M Kelly, Journal of Religin and Society Supplement Series 10 (The Kripke Center, 2014), 111-113.
} 
dilakukan oleh Lukas terhadap teks Yesaya tersebut.

\section{Konteks Lukas 4:18-19}

Analisis konteks ini akan berfokus pada Lukas 3:22-7:22. Tujuan dari analisis konteks ini adalah memahami bagaimana kisah di Nazaret terkait dengan beberapa bagian dari Injil Lukas dan menunjang karakteristik pelayanan Yesus sebagai Sang Mesias. Dari Lukas 3:22 akan terlihat bahwa peristiwa pembaptisan Yesus terkait dengan identitas Yesus sebagai Pribadi yang memiliki Roh Allah (bdk. 4:18). Lukas 7:22 mengulang kembali kelompok orang yang menjadi sasaran pelayanan Yesus, yang sebelumnya disebutkan dalam 4:18-19.

Pernyataan "Roh Tuhan ada pada-Ku, oleh sebab Ia telah mengurapi Aku ..."13 (4:18) memunculkan kembali gagasan yang sudah terlihat dalam peristiwa pembaptisan (Luk. 3:22). Kata "Roh" menjadi literary device penting dalam menunjukkan identitas Yesus yang dituliskan dalam 3:22-4:18. Hubungan antara peristiwa pembaptisan dan pernyataan Yesus dalam Lukas 4:18 menunjukkan landasan teologis bagi identitas Yesus sebagai Mesias yang diutus Allah.

Peristiwa pembaptisan $(3: 21-22)$ dan pencobaan (4:1-13) seperti sebuah permulaan bagi narasi Nazaret (Luk. 4:16-30). Kepemilikan Roh Tuhan dalam Lukas 4:18 mengingatkan pembaca tentang turunnya Roh Kudus atas Yesus dalam kisah pembaptisan (Luk. 3:22). Bisa dikatakan bahwa pengurapan Roh Kudus dalam Lukas 4:18 merujuk pada peristiwa baptisan. ${ }^{14}$ Kisah pembaptisan Yesus dilanjutkan dengan silsilah Yesus (3:23-38) yang menegaskan status-Nya sebagai Anak Allah. Ide yang sama muncul dalam peristiwa pembaptisan.

\footnotetext{
${ }^{13}$ Cetak miring oleh penulis.

${ }^{14}$ Charles H. Talbert, Reading Luke: $A$ Literary and Theological Commentary on the Third Gospel (New York: Crossroad, 1989), 55.
}

Gagasan Yesus sebagai Anak Allah tersebut diteruskan dan diperluas maknanya dalam kisah pencobaan di padang gurun (4:1-13). Yesus diperlihatkan sebagai Anak Allah yang taat kepada Bapa-Nya melalui kemenangan-Nya atas godaan Iblis. Kisah ini diawali dengan laporan bahwa Yesus penuh dengan Roh Kudus dan Roh Kudus membawa Yesus ke padang gurun (Luk. 4:1). Informasi tentang Roh Kudus tersebut menghubungkan perikop ini dengan kisah pembaptisan.

Ketika Yesus menyatakan, "Roh Tuhan ada pada-Ku" (Luk. 4:18), terlihat rangkaian kata "Roh" mulai dari Lukas 3:22 (lihat 4:1, 14). Penggunaan rangkaian kata tersebut memberi kejelasan identitas Yesus yang disampaikan dalam Lukas 4:18. Sebagai yang memiliki Roh Tuhan, Yesus adalah Anak Allah sejati. Identitas sebagai Anak Allah tersebut dimunculkan oleh Lukas 3:22, dan kemudian secara spesifik dipertegas dalam 4:1-13. Bukti bahwa Yesus adalah Anak Allah sejati terlihat dari ketaatan-Nya dengan tidak mengikuti godaan Iblis.

Arti penting frasa "Anak Allah" bagi posisi Yesus dalam konteks Injil Lukas harus dilihat berdasarkan berita malaikat kepada Maria (Luk. 1:32-35). Dalam bagian tersebut identitas Yesus sebagai Anak Allah yang dikandung dari Roh Kudus dihubungkan dengan identitas-Nya sebagai keturunan Daud. Dengan demikian, frasa "Anak Allah" dalam konteks ini terkait erat dengan keabsahan Yesus sebagai Sang Mesias yang diutus Allah. Peristiwa pembaptisan dan pencobaan memperlihatkan kelayakan Yesus untuk menjalankan tugas-Nya. Bagi pembaca Injil Ketiga hal tersebut merupakan dasar penting untuk memahami Yesus dan pelayanan-Nya dalam keseluruhan tulisan Lukas ini.

Dalam Lukas 7:22 dijumpai pernyataan yang menyerupai Lukas 4:18-19. Pernyataan tersebut merupakan respons Yesus terhadap pertanyaan Yohanes Pembaptis: "Engkau- 
kah yang akan datang itu atau haruskah kami menantikan seorang lain?" (Luk. 7:19, 20). Yesus menjawab: "Orang buta melihat, orang lumpuh berjalan, orang kusta menjadi tahir, orang tuli mendengar, orang mati dibangkitkan dan kepada orang miskin diberitakan kabar baik" (Luk. 7:22). Memang ada sedikit perubahan, namun bila dikategorikan, maka kelompok orang yang disebut dalam pernyataan tersebut sama dengan yang disebutkan dalam Lukas 4:18-19 (orang miskin, tawanan, buta dan tertindas), yaitu orang-orang yang terdiskriminasi.

Hal yang perlu menjadi perhatian terkait dengan hubungan antara Lukas 4:18-19 dengan 7:22 adalah karakter-karakter yang muncul di antara keduanya. Dalam Lukas 5:12-16, dikisahkan Yesus menyembuhkan seorang yang mengidap kusta. Lalu dalam perikop selanjutnya (5:17-26) Yesus menyembuhkan seorang yang lumpuh. Dikisahkan juga Lewi, pemungut cukai yang menjadi pengikut Yesus. Lalu di pasal 7 dicatat Yesus yang berinteraksi dengan seorang perwira Romawi (ay. 1-10) dan seorang janda (ay. 11-17). Karakter-karakter tersebut cocok dengan penggambaran kelompok orang yang dituliskan dalam Lukas 4:18-19 dan $7: 22$. Dengan demikian karakter-karakter tersebut menunjukkan realisasi dari pernyataan di kedua nas tersebut. Hal yang menarik adalah mereka merupakan orangorang yang secara sosial dan keagamaan adalah kelompok yang terpinggirkan.

Dari analisis konteks ini terlihat bahwa hubungan antara Lukas 4:18-19 dengan Lukas 3:22 dan bagian-bagian yang ada di antaranya menegaskan landasan teologis bagi identitas Yesus sebagai yang diutus Allah. Hubungan dengan Lukas 7:22 juga memperlihatkan bahwa mereka yang terpinggirkan adalah sasaran dari pelayanan Yesus.

\section{Signifikansi Kutipan dari Yesaya}

Lukas 4:18-19 merupakan bagian dari narasi khotbah di Nazaret. Narasi ini sering kali dilihat sebagai bentuk inaugurasi Yesus sebelum masuk ke dalam pelayanan. Secara spesifik perikop ini menunjukkan karakteristik pelayanan yang akan dilakukan oleh Yesus.

Lukas 4:18-19 merupakan kutipan dari Yesaya 61:1-2 yang dikombinasikan dengan $\mathrm{Ye}$ saya 58:6. Melalui kutipan ini, penulis Injil ketiga mencoba untuk menunjukkan bahwa Yesus dan pelayanan-Nya merupakan penggenapan dari Perjanjian Lama. Kutipan tersebut adalah landasan biblikal bagi pelayanan Yesus. Dengan demikian nas ini memiliki fungsi retorik untuk menjelaskan bahwa pelayanan Yesus merupakan bagian dari tradisi suci Israel. ${ }^{15}$

Jelas bahwa kutipan dari Yesaya (61:1-2; 58:6) dalam Lukas 4:18-19 berfokus pada Yesus. ${ }^{16}$ Secara substansial, pernyataan dari Yesaya tersebut menjelaskan identitas Yesus dan karakteristik dari misi yang akan dikerjakan-Nya. Berdasarkan Lukas 4:21, narasi Nazaret menampilkan Yesus sebagai penggenapan dari pernyataan Yesaya tersebut. Pernyataan tersebut terkesan dibaca oleh Yesus sebagai bentuk penugasan yang Ia terima dari Allah. ${ }^{17}$ Dengan demikian keberadaan dari kutipan Yesaya ini dapat dianggap sebagai scriptural framework bagi pelayanan Yesus dalam konteks Injil Ketiga. ${ }^{18}$ Dengan adanya kutipan dari Yesaya 61:1-2;

${ }^{15}$ Rebecca I. Denova, The Things Accomplished Among Us: Prophetic Tradition in the Structural Pattern of Luke-Acts (Sheffield: Sheffield Academic Press, 1997), 133.

${ }^{16}$ Kemunculan satu kata $\dot{\varepsilon} \mu \varepsilon \dot{\varepsilon}$ dan dua kata $\mu \varepsilon$ yang berasal dari akar kata $\dot{\varepsilon} \gamma \omega \dot{~ m e n g i n d i k a s i k a n ~ k e u t a m a a n ~}$ Yesus sebagai subyek dalam pernyataan Lukas 4:18.

${ }^{17}$ Robert C. Tannehill, Luke, Abington New Testament Commentary (Nashville: Abington, 1996), 91.

${ }^{18}$ Darrell Bock, Luke 1:1-9:50, Baker Exegetical Commentary on the New Testament. Grand Rapids: Baker, 1994), 404. 
58:6, pelayanan Yesus memiliki dasar dari Kitab Suci dan legitimasi bagi pelayanan tersebut berasal dari tradisi pengharapan mesianik Yudaisme. ${ }^{19}$ Bertolak dari hal ini, maka kutipan Yesaya tersebut memiliki peran retorik yang merupakan dasar meyakinkan bagi karakteristik pelayanan Yesus.

Dalam tradisi pengharapan mesianik di era Yudaisme Bait Suci Kedua, Yesaya 61:1-2 adalah salah satu teks biblikal dalam mendeskripsikan seorang utusan yang diurapi oleh Roh Kudus, misalnya dalam salah satu tulisan Qumran yang disebut 11QMelch. ${ }^{20}$ Tidak ada dasar yang pasti mendukung hubungan antara tulisan Qumran tersebut dengan Injil Ketiga. Namun, 11QMelch adalah contoh penting terkait penggunaan Yesaya 61:1-2 sebagai materi dalam menjelaskan figur yang diurapi oleh Roh. ${ }^{21}$ Dengan demikian tradisi penggunaan Yesaya 61:1-2 menjadi landasan untuk meyakini bahwa Yesus yang dipaparkan oleh Injil Ketiga merupakan bagian dari tradisi mesianik.

Selain itu, berdasarkan struktur dari Lukas 4:16-30 terlihat bahwa kutipan dari Yesaya dalam kisah Nazaret memiliki fungsi penting. Bila perikop ini disusun dalam bentuk kiasmus, maka akan terlihat bahwa kutipan tersebut berada pada pusat narasi. Hal ini dapat dilihat pada dua contoh format kiasmus berikut ini. ${ }^{22}$

\footnotetext{
${ }^{19}$ Denova, The Things Accomplished Among Us, 133.

${ }^{20}$ Pernyataan dari Kitab Yesaya yang muncul dalam 11QMelch terdapat pada baris 4, 6, 13, 14 dan 18-20. Lih. James A. Sanders, "From Isaiah 61 to Luke 4," dalam Luke and Scripture: The Function of Sacred Tradition in Luke-Acts, ed. Craig A. Evans and James A. Sanders (Oregon: Wipf and Stock, 2001), 56.

${ }^{21}$ Ibid., 56-57; lihat juga Merrill P. Miller, "Function of Isa 61:1-2 in 11Q Melchizedek," Journal of Biblical Literature 88, no. 4 (1969): 467-469.

${ }^{22}$ Berdasarkan Michael Prior, Jesus Liberation Theology (Luke 4. 16-30) (Sheffield: Sheffield Academic Press, 1995), 151-152.
}

\section{Contoh 1}
A lalu berdiri hendak membaca
B diberikan kitab nabi Yesaya
C setelah dibuka-Nya
D Roh Tuhan ada pada-Ku
C' Ia menutup kitab itu
B' memberikannya kembali
A' lalu duduk

Contoh 2

A Ia masuk ke rumah ibadah

B lalu berdiri hendak membaca

C diberikan kitab nabi Yesaya

D setelah dibuka-Nya

E Roh Tuhan ada pada-Ku

D' Ia menutup kitab itu

C' memberikannya kembali

B' lalu duduk

A' semua orang dalam rumah ibadah itu

Hal lain yang mengindikasikan signifikansi kutipan Yesaya dalam narasi Nazaret adalah isi dari kutipan tersebut. Kutipan tersebut menunjukkan bahwa Yesus adalah penggenapan dari figur mesianik yang digambarkan Yesaya. Dengan demikian, Yesaya 61:1-2; 58:6 merupakan kerangka konsep dalam memahami ciri dari pelayanan Yesus dalam Injil Lukas. ${ }^{23}$ Menghubungkan hal ini dengan fungsi kisah Nazaret sebagai programmatic narrative, maka teks Yesaya yang dikutip memiliki peran penting dalam menjabarkan bentuk misi Yesus dalam Injil Lukas. ${ }^{24}$

Jadi dari pemaparan pada bagian ini, dapat disimpulkan Yesaya 61:1-2; 58:6 memiliki signifikansi penting sebagai dasar bagi karakteristik pelayanan Yesus yang akan dijabarkan melalui kisah pelayanan publik Yesus di

\footnotetext{
${ }^{23}$ Craddock menjelaskan bahwa teks Yesaya menunjukkan bahwa Yesus adalah penggenapan nubuatan dan juga menunjukkan peran-Nya. Lih. Fred B. Craddock, Luke (Louisville: John Knox, 1990), 62.

${ }^{24}$ Prior, Jesus Liberation Theology, 15; Joel B. Green, The Theology of the Gospel of Luke (Cambridge: Cambridge University Press, 1995), 76; Philip Francis Esler, Community and Gospel in Luke-Acts: The Social and Political Motivation of Lucan Theology (Cambridge: Cambridge University Press, 1989), 164.
} 
seluruh Injil Lukas. Di bagian selanjutnya akan dijabarkan bagaimana Lukas menggunakan teks Yesaya tersebut sedemikian rupa untuk memperkuat dimensi sosial dari pelayanan Yesus.

\section{Modifikasi Kutipan dari Yesaya}

Memahami bagaimana Lukas menggunakan teks Yesaya yang dikutipnya akan menolong untuk melihat dimensi sosial yang ingin ditekankan oleh Injil ini. Teks Yesaya tersebut digunakan dengan beberapa modifikasi yang memungkinkan penegasan terhadap kepedulian sosial. Dalam konteks aslinya, Yesaya 61:1-2 adalah bagian dari berita tentang restorasi Yerusalem. Pesan Yesaya 61 secara keseluruhan berkaitan dengan pemulangan Israel dari pembuangan. Dalam tabel berikut ini akan terlihat persamaan dan perbedaan antara Lukas 4:18-19 dan Yesaya 61:1-2; 58:6.

Tabel 2 Perbandingan Lukas 4:18-19 dan Yesaya 61:1-2; 58:6

Lukas 4:18-19 $\quad$ Yesaya 61:1-2; 58:6

"Roh Tuhan ada pada-Ku, oleh sebab Ia telah mengurapi Aku, untuk menyampaikan kabar baik kepada orang-orang miskin;

dan Ia telah mengutus Aku untuk memberitakan pembebasan ( $\ddot{\alpha} \varphi \varepsilon \sigma \iota)$ kepada orangorang tawanan,

dan penglihatan bagi orang-orang buta,

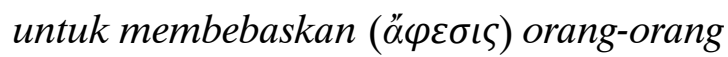
yang tertindas, ${ }^{25}$

untuk memberitakan tahun rahmat Tuhan telah datang."
Roh Tuhan ALLAH ada padaku, oleh karena Tuhan telah mengurapi aku; Ia telah mengutus aku untuk menyampaikan kabar baik kepada orang-orang sengsara,

dan merawat orang-orang yang remuk hati, ${ }^{26}$

untuk memberitakan pembebasan kepada orang-orang tawanan, dan kepada orangorang yang terkurung kelepasan dari penjara,

[Bukan! Berpuasa yang Kukehendaki, ialah supaya engkau membuka belenggu-belenggu kelaliman, dan melepaskan tali-tali kuk, supaya engkau memerdekakan (ó $\varphi \varepsilon \sigma 1 \varsigma)^{27}$ orang yang teraniaya ${ }^{28}$ dan mematahkan setiap kuk] (58:6)

untuk memberitakan tahun rahmat Tuhan

dan hari pembalasan Allah kita, untuk menghibur semua orang berkabung. ${ }^{29}$

\footnotetext{
${ }^{25}$ Tambahan dari Yesaya 58:6.
}

\footnotetext{
${ }^{26}$ Tidak dimuat dalam Lukas 4:18-19.

${ }^{27}$ Berdasarkan LXX.

${ }^{28}$ Bandingkan yang bercetak miring dengan terjemahan NASB, NRSV dan ESV. Kata "teraniaya" diterjemahkan "oppressed."

${ }^{29}$ Tidak dimuat dalam Lukas 4:18-19.
} 
Ketika Yesaya 61:1-2 ditempatkan dalam Lukas 4:18-19, penulis tidak menyertakan "hari pembalasan Allah kita" (Yes. 61:2). Terkesan bahwa Lukas ingin mengurangi nuansa politis dari Yesaya $61 \mathrm{demi}$ mempertegas aspek spiritualnya. Kutipan ini juga dikombinasikan dengan pernyataan "membebaskan orang-orang yang tertindas" yang terambil dari Yesaya 58:6. Dengan kombinasi dari Yesaya 58:6 ini, restorasi dalam Lukas 4:18-19 bukan saja berdimensi spiritual namun, secara luas atau holistik, juga memiliki dimensi sosial.

Di samping itu, Lukas 4:18-19 juga tidak memuat pernyataan "merawat orang-orang yang remuk hati." Mengenai frasa ini, menurut $\mathrm{NA}^{28}$ di beberapa manuskrip pernyataan tersebut dicantumkan (misalnya $\mathrm{A}, \Delta, \Theta, \Psi$, $f^{1}$ ), namun tidak terdapat pada beberapa manuskrip teks yang lebih tua $(\mathrm{\kappa}, \mathrm{B}, \mathrm{D}) .^{30}$ Marshall beranggapan bahwa pembacaan yang panjang lebih bisa diterima karena akan menjadi dasar bagi kata "tabib" (physician) di Lukas 4:23. ${ }^{31}$ Namun ada indikasi yang cukup kuat bahwa manuskrip yang tetap mempertahankan frasa "merawat orangorang yang remuk hati" mengikuti terjemahan LXX. ${ }^{32}$ Namun demikian, menurut UBS $^{5}$ pembacaan yang lebih pendek dipandang sebagai yang terbaik, sebagaimana nanti akan diuraikan selanjutnya bahwa dengan pengabaian ini, memungkinkan Lukas untuk mempertegas kata ő $\varphi \varepsilon \sigma ı$.

Salah satu asumsi terkait diabaikannya frasa "merawat orang-orang yang remuk hati"

${ }^{30}$ Lihat Eberhard Nestle, Erwin Nestle, Barbara Aland, Kurt Aland, Johannes Karavidopoulos, Carlo M. Martini, dan Bruce M. Metzger, ed., Novum Testamentum Graece, ed. ke-28 (Stuttgart: Deutsche Biblegesellschaft, 2012), 193.

${ }^{31}$ I. Howard Marshall, The Gospel of Luke: A Commentary on the Greek Text, New International Greek Testament Commentary (Grand Rapids: Eerdmans, 1978), 182.

${ }^{32}$ Bruce M. Metzger, A Textual Commentary on the Greek New Testament, ed. ke-2 (Stuttgart: German Bible Society, 1994), 114. adalah dimasukkannya Yesaya 58:6, "memerdekakan ( $\alpha \varphi \varepsilon \sigma ı))$ orang yang teraniaya" ke dalam teks Lukas 4:18 yang berbunyi "membebaskan (ö $\varphi \varepsilon \sigma i \varsigma)$ orang-orang yang tertindas" dengan tujuan untuk menekankan kata $\alpha \varphi \varepsilon \sigma i \varsigma$ (membebaskan). Kata tersebut adalah catchword yang membuat kesesuaian antara Yesaya 58:6 dengan 61:1-2, sehingga keduanya memungkinkan untuk dipadukan. $^{33}$

Dengan dimasukkannya Yesaya 58:6 ke dalam Yesaya 61:1-2, maka terdapat dua pernyataan yang menggunakan ö $\varphi \varepsilon \sigma ı \varsigma$, yaitu: (1) "untuk memberitakan pembebasan (ö $\varphi \varepsilon \sigma 1 \varsigma)$ kepada orang-orang tawanan"; dan (2) "untuk membebaskan ( $\alpha \varphi \varepsilon \sigma ı \varsigma)$ orangorang yang tertindas." Dalam Injil Lukas, pembebasan adalah salah satu gagasan penting (Luk. 1:77; 3:3; 24:47; lih. juga Kis. 2:38; $5: 31 ; 10: 43 ; 13: 38 ; 26: 18)$. Pembebasan di sini memang terkait dengan pembebasan dari dosa. Namun, karena penggunaan ö $\varphi \varepsilon \sigma 1 \varsigma$ dalam Lukas 4:19 salah satunya terambil dari Yesaya 58:6, maka ide pembebasan di sini memiliki makna yang holistik.

Yesaya 58:6 berasal dari konteks di mana Israel ditegur keras karena mereka mengabaikan keadilan sosial pada saat mereka melakukan kegiatan keagamaan, dalam hal ini adalah berpuasa. Berpuasa yang diinginkan oleh Allah bukan semata yang bersifat ritualistik, tetapi puasa dalam bentuk upaya membebaskan mereka yang tertindas dan menolong mereka yang berkekurangan (Yes. 58:5-7).

Dengan disertakannya Yesaya 58:6, maka Lukas memperluas makna Yesaya 61:1-2. Yesaya 58:6 menempatkan pelayanan Yesus ke dalam konteks di mana kepedulian sosial

${ }^{33}$ Menurut Fitzmyer, kata $\ddot{\alpha} \varphi \varepsilon \sigma 1 \varsigma$ mengikat Yesaya 61:1-2 dan 58:6, sehingga dengan diabaikannya "merawat orang-orang yang remuk hati," memungkinkan Lukas untuk menekankan ide pembebasan yang penting dalam pasal 4:19. Lih. Joseph A. Fitzmyer, The Gospel According to Luke I-IX (Garden City: Doubleday, 1981), 533. 
menjadi unsur yang penting. ${ }^{34}$ Karena kutipan Yesaya dalam konteks Lukas 4:16-30 memiliki fungsi memberi gambaran tentang pelayanan Yesus, maka pelayanan tersebut diwarnai dengan gagasan kepedulian sosial. Keberadaan Yesaya 58:6 mempertegas hal tersebut, sebagaimana dijelaskan oleh Byrne:

The importing of a phrase from this passage into the text of Isa 6:1-2 quoted by Jesus brings with it the content of the wider passage from which it comes. It fills out the sense of releasing the oppressed with the wider program of social justice and hospitality to the poor announced in v. 7. Understood in this way, it implies that the ministry of Jesus will fulfill the program of social justice that, according to Isaiah 58, God required of Israel. This greatly enriches the significance of the whole. ${ }^{35}$

Penjelasan di atas menunjukkan bahwa gagasan pembebasan memiliki aspek sosial. Aspek sosial tersebut terletak pada kerangka pikir Kristologis Lukas yang menunjukkan bahwa Yesus adalah penggenapan dari figur mesianik Yesaya yang membawa pembebasan. Di samping itu, dengan adanya modifikasi yang dilakukan terhadap teks Yesaya tersebut, Lukas memperluas makna pembebasan yang dituliskannya. Karena pembalasan terhadap musuh-musuh Israel tidak dimasukkan dalam kutipan, maka pembebasan yang dimaksud oleh Lukas tidaklah bersifat politis dan tidak eksklusif hanya kepada Israel. Pembebasan tersebut bisa dinikmati oleh siapa saja melalui Kristus, dan pembebasan tersebut memiliki makna yang luas mencakup aspek spiritual (dari dosa) dan

\footnotetext{
${ }^{34}$ Dengan mengabaikan "merawat orang-orang yang remuk hati" dan memasukkan "membebaskan orangorang yang tertindas," Lukas mempertajam dimensi sosial dari kutipan Yesaya. Lihat Jacques Matthey, "Luke 4:16-30-the Spirit's Mission Manifesto-Jesus' Hermeneutics-and Luke's Editorial," International Review of Mission 89, no. 352 (2000): 4.

${ }^{35}$ Brendan Byrne, The Hospitality of God: A Reading of Luke's Gospel (Collegeville: Liturgical, 2000), 49.
}

sosial (dengan bertolak pada penggunaan Yesaya 58:6).

Bila dihubungkan dengan keseluruhan dari bagian Injil Lukas, maka dimensi sosial yang didasarkan pada Lukas 4:18-19 selaras dengan cara bagaimana Injil Ketiga ini memahami misi Allah. Berdasarkan perspektif teologis, dengan menggunakan Yesaya 58:6, Injil Lukas menekankan kepedulian sosial yang asal mulanya bertolak dari karakteristik misi Allah. Nyanyian Maria dalam Lukas 1:46-56 menghubungkan kedatangan Yesus dengan karya Allah yang agung. Salah satu aspek dari karya tersebut adalah kepedulian terhadap mereka yang lapar (Luk. 1:53). Hal ini memiliki kesamaan dengan konteks Yesaya 58:6 yang menggambarkan Allah yang memiliki kepedulian sosial: Allah memerintahkan umat-Nya untuk memperhatikan keadilan (justice) sebagai bagian dari praktik keagamaan mereka. Ide yang sama juga muncul pada "Ucapan Bahagia" versi Lukas (Luk. 6:20-45): karya Allah melalui Sang Mesias memiliki manfaat bagi mereka yang secara sosial lemah.

Kutipan Yesaya ini juga memiliki implikasi teologis. Secara umum, penggunaan Yesaya 61:1-2; 58:6 menghubungkan pelayanan Yesus dengan kerangka pikir teologis yang lebih luas. Kutipan tersebut merefleksikan tradisi gereja mula-mula dalam menggunakan teks Alkitab untuk menghubungkan secara teologis, karya Yesus dengan karya Allah. ${ }^{36}$ Dari perspektif intertekstualitas dalam sebuah narasi, Joel B. Green beranggapan bahwa kutipan dari Perjanjian Lama dalam kaitan pelayanan Yesus, menghubungkan misi Yesus dengan narasi Allah. ${ }^{37}$ Khusus untuk Lukas 4:16-30, kutipan biblikal dalam ayat 18-19 menghubungkan karya Yesus dengan tujuan Allah. Tannehill menjelaskan:

\footnotetext{
${ }^{36}$ Sanders, "From Isaiah 61," 15

${ }^{37}$ Joel B. Green, "Narrative Criticism," dalam Methods for Luke (Cambridge: Cambridge University Press, 2010), 98.
} 
The quotation from Isaiah which Jesus reads in the Nazareth synagogue fits all four of these categories. As Scripture, it is viewed as testimony to God's purpose. As a statement by Jesus, it comes from the human character of highest authority within the narrative. It is a statement of what the Lord has sent Jesus to do, i.e., a statement of Jesus' commission, which should lead us to expect that it is also a preview of what Jesus will in fact be doing in the following narrative. ${ }^{38}$

Unsur implikasi teologis dari kutipan Yesaya ini menegaskan bahwa dimensi sosial yang termuat dalam pelayanan Yesus memiliki landasan teologis. Kepedulian sosial dalam pelayanan Yesus tidak bisa dilepaskan dari tujuan Allah dalam mengutus Yesus sebagai Sang Mesias.

\section{IMPLIKASI BAGI REVITALISASI PELAYANAN KRISTEN}

Dalam bagian ini akan disajikan bahwa kepedulian sosial adalah panggilan ilahi. Sebagaimana pelayanan Yesus yang memiliki dasar teologis untuk menerapkan kepedulian sosial, maka gereja pun terpanggil untuk melakukan pelayanan yang sama, menunjukkan kepedulian Allah terhadap mereka yang secara sosial ekonomi lemah. Bagian ini juga akan menunjukkan bahwa spiritulitas pelayanan Kristen tidak bersifat dualistik, memisahkan unsur materiel dan imateriel. Hubungan antara gereja dan Allah harus nampak pada hubungan dengan sesama.

\section{Kepedulian Sosial dalam Pelayanan Kristen adalah Panggilan Ilahi}

Berdasarkan analisa di atas jelas bahwa kutipan Yesaya dalam Lukas 4:18-19 menunjukkan pelayanan Yesus memiliki dimensi

${ }^{38}$ Robert C. Tannehill, The Narrative Unity of LukeActs: A Literary Interpretation (Philadelphia: Fortress, 1986), 1:61. sosial. Hubungan naratif Nazaret dengan bagian lainnya dari Injil Lukas memperlihatkan bahwa misi Yesus terkait dengan karya Allah yang peduli terhadap mereka yang lemah secara sosial ekonomi. Dengan demikian kepedulian sosial dalam pelayanan Yesus berasal dari kepedulian Allah terhadap mereka yang terdiskriminasi karena status sosial mereka. Maka kepedulian sosial tersebut adalah panggilan yang Yesus terima dari Allah.

Dalam kitab Kisah Para Rasul, para rasul yang adalah penerus dari pelayanan Yesus, mendemonstrasikan karakteristik pelayanan yang sama. Bila dibandingkan dengan Yesus, para murid memulai pelayanan mereka setelah mereka dipenuhi Roh (Kis. 1:8; 2:113; bandingkan Luk. 3:22-4:19). Para pembaca Kisah Para Rasul dapat melihat dimensi sosial dari pelayanan para murid dalam $2: 44-45 ; 4: 32-37$. Komunitas gereja perdana menggunakan harta milik mereka untuk membantu mereka yang miskin.

Menghubungkan hal di atas dengan kepedulian sosial yang harus diterapkan dalam pelayanan Kristen, artikel ini beranggapan bahwa kepedulian sosial tersebut adalah bagian dari panggilan Allah bagi gereja. Pernyataan dalam Lukas 10:27 mengindikasikan bahwa mengasihi Allah dan mengasihi sesama adalah sama pentingnya. Gagasan tentang mengasihi sesama tercermin pada perintah untuk menggunakan harta sebagai sedekah (Luk. 11:41; 12:33; 18:22; 19:8). Gagasan ini selaras dengan bagian dari Perjanjian Baru lainnya. Seperti yang sudah dilihat di atas, bahwa memberi bantuan kepada yang miskin adalah ciri dari jemaat perdana (Kis. 2:44-45; 4:32-37).

Contoh lain dapat dilihat pada pelayanan Paulus. Dalam Galatia 2:10, Paulus menyatakan keseriusannya dalam memberi perhatian terhadap mereka yang miskin. Secara praktis, perhatian Paulus terhadap mereka yang miskin terimplementasi dalam upaya- 
nya untuk mengumpulkan bantuan dana bagi saudara-saudara yang miskin di Yerusalem (Kis. 11:29-30; Rom. 15:25-26). Di samping tindakan yang dilakukan oleh Paulus, contoh lain dapat kita lihat pada anjuran dalam Yakobus 1:27: spiritualitas yang selaras dengan kehendak Allah adalah kepedulian terhadap para yatim piatu dan janda. Berdasarkan hal-hal tersebut, bagian lain Perjanjian Baru juga mendukung analisis artikel ini terhadap Lukas 4:18-19 (dan hubungannya dengan bagian lain dari Injil Lukas) bahwa kepedulian sosial adalah bagian integral dari pelayanan Kristen. Bahkan kepedulian sosial tersebut adalah panggilan bagi umat Kristen, yang bukan sekadar muncul dari kesadaran adanya kebutuhan di antara umat dan masyarakat.

Panggilan sosial ini bisa dipahami sebagai tanggung jawab sosial gereja. Dengan panggilan sosial yang dimilikinya, gereja adalah agen yang bertanggung jawab membawa pemulihan bagi manusia. Pemulihan tersebut secara luas dapat menyentuh isu-isu sosial yang ada di sekitar gereja-kemiskinan, hak asasi, kesetaraan gender, kerusakan lingkungan. Studi dari artikel ini memperlihatkan bahwa panggilan sosial tersebut memiliki landasan teologis, maka, sebagaimana halnya dengan pelayanan Yesus, pelayanan gerejawi harus menyentuh kebutuhan manusia secara luas, termasuk mengangkat perekonomian mereka agar hidup lebih layak. Hal yang bisa dilakukan adalah dengan menerapkan pelayanan diakonia yang lebih bersifat sistematis, tidak sekadar situasional. Pelayanan diakonia juga harus bersifat transformatif dengan menerapkan program-program yang tepat dalam mengangkat perekonomian jemaat, bukan hanya sekadar memberikan santunan seadanya.

Pelayanan Yesus dalam Injil Lukas yang didasari oleh Yesaya 61:1-2; 58:6 menegaskan bahwa karya-Nya merupakan contoh dari wujud pelayanan yang berinteraksi dengan manusia dalam situasi sosial yang mereka hadapi. Ini merupakan pengejawantahan keberpihakan Allah terhadap mereka yang secara sosial lemah. Interaksi Yesus tersebut dipahami oleh Matthias Börner sebagai upaya membuat manusia bisa mengalami kasih Allah. ${ }^{39}$

\section{Spiritualitas Pelayanan Kristen}

Karakteristik pelayanan Yesus yang tercermin di Lukas 4:18-19 memiliki signifikansi bagi spiritualitas pelayanan Kristen. Dengan mengacu kepada dimensi sosial pelayanan Yesus, maka terlihat bahwa spiritualitas pelayanan Kristen tidak bersifat dualistik, memisahkan hal materiel dan imateriel. Spiritualitas dapat dipahami sebagai bentuk praktikal dari sebuah religiositas. ${ }^{40}$ Secara spesifik, spiritualitas adalah praktik religiositas yang didasarkan pada hubungan dengan Allah. ${ }^{41}$ Lukas 4:18-19 menunjukkan bagaimana Yesus memahami relasinya dengan Allah. Penulis Injil Lukas menghubungkan karya Yesus dengan karya Allah yang berpihak kepada mereka yang lemah secara sosial ekonomi (Luk. 1:53). Terdapat keselarasan antara sifat Allah tersebut dengan bentuk pelayanan Yesus. Secara praktis, pelayanan Yesus juga memiliki keberpihakan terhadap mereka yang terpinggirkan.

Dimensi sosial dalam pelayanan Yesus tidak dapat dilepaskan dari hubungan-Nya dengan Allah. Hubungan Yesus secara vertikal dengan Allah mempengaruhi hubungannya secara horizontal dengan sesama. Pelayanan-Nya memiliki kepedulian terhadap mereka yang miskin. Prinsip ini menunjukkan bahwa spiritualitas Kristen harus dapat dibuktikan melalui hubungan dengan sesama.

\footnotetext{
${ }^{39}$ Matthias Börner, "The Churches and Their Social Responsibility. A Christian Perspective," European Judaism: A Journal for the New Europe 46, no. 1 (2013): 88.

${ }^{40}$ Helmut Burkhard, "Spirituality and Ethics," European Journal of Theology 19 (2010): 45.

${ }^{41}$ F. L. Cross dan Elizabeth A. Livingstone, ed., Dictionary of the Christian Church (Peabody: Hendrickson, 2007), 1532.
} 
Seperti yang dikatakan oleh Helmut Burkhart, "Spirituality and the sphere of interhuman responsibility may not be divided. The first has to prove itself in the realm of the second." 42

Pola spiritualitas yang holistik ini juga menentukan upaya gereja dalam memahami konsep pembebasan yang dialami dalam Kristus. David Jacobus Bosch memahami bahwa konsep pembebasan dalam Injil Lukas bermakna luas. Pembebasan pertama tentu berkaitan dengan pengampunan dosa. Namun, juga tidak bisa dipungkiri bahwa pembebasan tersebut juga terkait dengan kehidupan sosial manusia. Bosch mengatakan bahwa keselamatan "... includes the total transformation of human life, forgiveness of sin, healing from infirmities, and release from any kind of bondage (Luke uses aphesis for both 'forgiveness' and 'release' or 'liberation': compare 24:47 with 4:18)." ${ }^{43}$ Bosch juga menjelaskan bahwa keselamatan "involves the reversal of all the evil consequences of sin, against both God and neighbor." ${ }^{44}$

Konsep spiritualitas nondualistik menjadi dasar bagi gereja dalam memahami restorasi yang harus dialami manusia. Pemulihan terhadap unsur imateriel tidak bisa dipisahkan dari pemulihan unsur materiel. Upaya gereja mengangkat kehidupan mereka yang lemah secara sosial ekonomi merupakan bentuk kesadaran bahwa hubungan gereja dengan Allah harus dapat dijelmakan melalui kepedulian terhadap sesama.

\section{KESIMPULAN DAN SARAN}

Tantangan yang harus dihadapi oleh gereja dalam menerapkan pelayanan adalah dualisme yang memisahkan hal materiel dari imateriel. Ini mengakibatkan kepedulian sosial

\footnotetext{
${ }^{42}$ Burkhard, "Spirituality and Ethics," 48.

${ }^{43}$ David Jacobus Bosch, Transforming Mission: Paradigm Shifts in Theology of Mission (Maryknoll: Orbis Books, 1991), 107.

${ }^{44}$ Ibid.
}

menjadi hal yang terabaikan. Studi dari artikel ini terhadap karakteristik pelayanan Yesus dalam Lukas 4:18-19 menunjukkan bahwa pelayanan Kristen harus meneladani pelayanan Yesus yang memiliki dimensi sosial. Kepedulian sosial adalah panggilan ilahi yang harus diterapkan, dan juga merupakan bagian dari spiritualitas pelayanan Kristen.

Menyikapi gagasan di atas, maka gereja perlu untuk mengembangkan pelayanan yang menjawab kebutuhan jemaat, termasuk kebutuhan materiel mereka. Restorasi kehidupan anggota jemaat seharusnya tidak dipahami secara dualistik. Secara praktis, yang gereja dapat lakukan untuk menyikapi kemiskinan di sekitarnya adalah mengembangkan pelayanan diakonia yang sistematis.

Pelayanan diakonia tidak dilakukan semata sebagai pelayanan sekunder yang sifatnya situasional. Teologi yang dibangun untuk melandasi diakonia gereja harus menjelaskan bahwa pelayanan sosial terhadap mereka yang membutuhkan juga merupakan panggilan ilahi dan karakter spiritualitas Kristen. Dimensi sosial pelayanan Yesus Kristus dalam Injil Lukas dapat menjadi salah satu contoh biblikal dalam membangun konsep teologi tersebut.

Artikel ini tentu hanya menyentuh beberapa unsur saja dari landasan panggilan sosial gereja. Dalam penelitian-penelitian selanjutnya yang memiliki tujuan dan topik yang sama, dapat dikembangkan beberapa aspek. Misalnya, mendalami implementasi dimensi sosial dari pelayanan Yesus di tengah-tengah pelayanan dan kehidupan jemaat mula-mula sebagaimana tercatat dalam Kisah Para Rasul. Dalam tulisan jilid keduannya ini, Lukas memberikan gambaran umum kehidupan jemaat mula-mula yang memiliki perhatian terhadap mereka yang lemah secara ekonomi (Kis. 2:41-47; 4:32-37). Keseriusan gereja mula-mula terhadap pelayanan membantu mereka yang lemah secara sosial ekonomi juga terlihat secara implisit dalam 
kisah Ananias dan Safira (Kis. 5:1-11) dan pemilihan tujuh diaken yang menangani bantuan terhadap para janda (Kis. 6:1-7). Tinjauan terhadap bagian-bagian dari Kisah Para Rasul tersebut akan menjadi keberlanjutan yang signifikan dari apa yang telah dianalisis dan dipaparkan artikel ini, yaitu bahwa kepedulian sosial dalam pelayanan Yesus diteruskan oleh gereja perdana, melalui tradisi pelayanan diakonia mereka, seperti yang tercemin dalam keseluruhan tulisan Lukas

\section{DAFTAR KEPUSTAKAAN}

Bock, Darrell L. Luke 1:1-9:50. Baker Exegetical Commentary on the New Testament. Grand Rapids: Baker Books, 1994.

Börner, Matthias. "The Churches and Their Social Responsibility. A Christian Perspective." European Judaism: A Journal for the New Europe 46, no. 1 (2013): 8089.

Bosch, David Jacobus. Transforming Mission: Paradigm Shifts in Theology of Mission. Maryknoll: Orbis Books, 1991.

Burkhard, Helmut. "Spirituality and Ethics." European Journal of Theology 19 (2010): 45-49.

Burridge, Richard. "Gospel Genre, Christological Controversy and the Absence of Rabbinic Biography: Some Implications of the Biographical Hypothesis." Dalam Christology, Controversy and Community: New Testament Essays in Honor of David $R$. Catchpole, diedit oleh David G. Horrell dan Christopher M. Tuckett, 137156. Leiden: Brill, 2000.

Byrne, Brendan. The Hospitality of God: A Reading of Luke's Gospel. Collegeville: Liturgical, 2000.

Cadbury, Henry J. The Making of Luke-Acts. Peabody: Hendrickson, 1999.

Calef, Susan. "Prophet Margins' in the Economy of Salvation." Dalam The Bible, the Economy, and the Poor, diedit oleh Ronald A Simkins dan Thomas M Kelly, 106-131. Journal of Religion and
Society Supplement Series 10. The Kripke Center, 2014.

Craddock, Fred B. Luke. Louisville: John Knox, 1990.

Cross, F. L., dan Elizabeth A. Livingstone, ed. Dictionary of the Christian Church. Peabody: Hendrickson, 2007.

De Chickera, Duleep. "Victim Theology and the Economy of Life: Some Lessons." Ecumenical Review 67, no. 2 (2015): 277 $-284$.

Denova, Rebecca I. The Things Accomplished Among Us: Prophetic Tradition in the Structural Pattern of Luke-Acts. Sheffield: Sheffield Academic Press, 1997.

DeSilva, David A. An Introduction to the New Testament: Contexts, Methods \& Ministry Formation. Downers Grove: InterVarsity Press, 2004.

Esler, Philip Francis. Community and Gospel in Luke-Acts: The Social and Political Motivation of Lucan Theology. Cambridge: Cambridge University Press, 1989.

Fitzmyer, Joseph A. The Gospel According to Luke I-IX. Garden City: Doubleday, 1981.

Green, Joel B. "Narrative Criticism." In Methods for Luke, 74-112. Cambridge: Cambridge University Press, 2010.

- The Gospel of Luke. The New International Commentary on the New Testament. Grand Rapids: Eerdmans, 1997.

- The Theology of the Gospel of Luke. Cambridge: Cambridge University Press, 1995.

Johnson, Luke Timothy. The Gospel of Luke, diedit oleh Daniel J. Harrington. Sacra Pagina Series 3. Collegeville: The Liturgical, 1991.

Kloppenborg, John S. "Gospels.” In The Oxford Encyclopedia of the Books of the Bible. Vol. 1. Diedit oleh Michael Coogan, 334-349. Oxford: Oxford University Press, 2011.

Marshall, I. Howard. The Gospel of Luke: A Commentary on the Greek Text. New International Greek Testament Commen- 
tary. Grand Rapids: Eerdmans, 1978.

Matthey, Jacques. "Luke 4:16-30-the Spirit's Mission Manifesto-Jesus' Hermeneutics-and Luke's Editorial." International Review of Mission 89, no. 352 (2000): 3-11.

Metzger, Bruce M. A Textual Commentary on the Greek New Testament. Ed. ke-2. Stuttgart: German Bible Society, 1994.

Miller, Amanda C. "Bridge Work and Seating Charts: A Study of Luke's Ethics of Wealth, Poverty, and Reversal." Interpretation: A Journal of Bible and Theology 68, no. 4 (2014): 416-427.

Miller, Merrill P. "Function of Isa 61:1-2 in 11Q Melchizedek." Journal of Biblical Literature 88, no. 4 (1969): 467-469.

Nestle, Eberhard, Erwin Nestle, Barbara Aland, Kurt Aland, Johannes Karavidopoulos, Carlo M. Martini, dan Bruce M. Metzger, ed. Novum Testamentum Graece. Ed. ke-28. Stuttgart: Deutsche Biblegesellschaft, 2012.

Prior, Michael. Jesus Liberation Theology (Luke 4. 16-30). Sheffield: Sheffield Academic Press, 1995.

Resseguie, James L. Narrative Criticism of the New Testament: An Introduction. Grand Rapids: Baker Academic, 2005. Sanders, James A. "From Isaiah 61 to Luke 4." Dalam Luke and Scripture: The Function of Sacred Tradition in LukeActs, diedit oleh Craig A. Evans dan James A. Sanders, 46-69. Oregon: Wipf and Stock, 2001.

Sukamto, Amos. Pelayanan Gereja Di Indonesia Pada Era Reformasi. Jakarta: Tim Publikasi ICDS, 2003.

Talbert, Charles H. Reading Luke: A Literary and Theological Commentary on the Third Gospel. New York: Crossroad, 1989.

Tannehill, Robert C. Luke. Abington New Testament Commentary. Nashville: Abington, 1996.

. The Narrative Unity of Luke-Acts: A Literary Interpretation. 2 vol. Philadelphia: Fortress, 1986.

"Kementerian Agama Dalam Angka 2016." Biro Hubungan Masyarakat, Data dan Informasi Sekretariat Jenderal Kementrian Agama, 2017.

"Profil Kemiskinan Di Indonesia September 2018.” Badan Pusat Statistik, 2019. 